\title{
Breast Milk Donation in the Muslim Population: Why It Is Possible
}

\author{
Virginie Rigourd $^{1}{ }^{\text {* }}$, Muriel Nicloux ${ }^{1}$, Agnès Giuseppi ${ }^{1}$, Stéphanie Brunet ${ }^{1}$, Daniel Vaiman ${ }^{2}$, \\ Rafik TerkiHassaine ${ }^{3}$, Sabrina Jébali ${ }^{1}$, Zalfa Kanaan ${ }^{1}$, Azzedine Ayachi ${ }^{4}$ \\ ${ }^{1}$ Necker Enfants Malades Hospital, Paris, France \\ ${ }^{2}$ Epigenetic and Physiopathology of Reproduction, Cochin Hospital, Paris, France \\ ${ }^{3}$ West Algerian Pediatric Society, Oran, Algeria \\ ${ }^{4}$ Intercommunal André Grégoire Hospital, Montreuil, France
}

Email address:

virginie.rigourd@nck.aphp.fr(V.Rigourd)

${ }^{*}$ Corresponding author

\section{To cite this article:}

Virginie Rigourd, Muriel Nicloux, Agnès Giuseppi, Stéphanie Brunet, Daniel Vaiman, Rafik TerkiHassaine, Sabrina Jébali, Zalfa Kanaan, Azzedine Ayachi. Breast Milk Donation in the Muslim Population: Why It Is Possible. American Journal of Pediatrics.

Vol. 4, No. 1, 2018, pp. 12-14. doi: 10.11648/j.ajp.20180401.13

Received: January 28, 2018; Accepted: March 5, 2018; Published: March 30, 2018

\begin{abstract}
Some mothers have negative ideas about human milk donation, especially in the Muslim population, because of the «milk brother-sister» concept, whereas infants are often in need of human milk. A mother delivered a very low birth-weight infant of $500 \mathrm{~g}$ after 26 weeks of amenorrhea. She was able to collect $200 \mathrm{~mL}$ of milk per day by four days after birth, $500 \mathrm{ml} /$ day after seven, and then up to $1.5 \mathrm{~L} /$ day. At the end of the hospitalization, the milk bank asked her if she was willing to donate her milk. She first refused to offer her milk for donation because of the «brother milk» concept. After discussion, the milk-bank team managed to convince the mother to donate the 179 Liters of milk not used by her baby. The two issues that may arise for a Muslim are whether they allowed to donate their own milk and whether their infant can receive donated milk. These issues were addressed by: i) performing a literature review covering all points of view of the religion concerning human milk donation, ii) seeking the expertise of religious figures, and iii) examining biological and genetic issues. Thus, religious, cultural, biological, and epigenetic aspects all support milk donation by Muslim mothers to milk banks and allow children to receive donated milk. Milk banks should be created in Muslim countries to promote the health of pre-term infants.
\end{abstract}

Keywords: Human Milk Bank, Muslim, Milk Donation, Preterm, Breastfeeding

\section{Introduction}

When a mother's own milk is unavailable or in short supply, donated pasteurized human milk (DHM) can be used in neonatal intensive care units. There is increasing evidence and numerous expert opinions to support the use of DHM for hospitalized preterm infants. However, the use of DHM is not growing in countries with a predominantly Muslim population. The religious objection centers around the Islamic concept that consuming human milk from the same donor builds a kinship bond between individuals and prohibits future marriage between «milk-brothers and sisters».

\section{Methods}

To respond to the two principal concerns of Muslim mothers (whether they can donate their own milk and whether their infant can receive DHM) and promote milk donation, a review of various opinions and those of religious leaders was conducted and biological and genetic data were used to remove the sibling barrier and convince Muslim mothers to donate.

\section{Result}

A 28-year-old Muslim mother who had a C-section at 26 
weeks GA gave birth to a very low birth-weight infant of no more than $500 \mathrm{~g}$. The baby survived many classical prematurity complications during his hospitalization in the neonatal intensive care unit (NICU). The mother was able to collect $200 \mathrm{~mL}$ of milk per day after four days, $500 \mathrm{ml} /$ day after seven, and then up to $1.5 \mathrm{~L} /$ day. She collected a total of $179 \mathrm{~L}$ of milk not used by her baby. She initially refused to donate the extra milk because of the milk kinship concept. After discussion, the milk-bank group convinced the Muslim mother to donate her 179 Liters of milk, as she was unable to store it at home due to insufficient space. This donated milk was used to feed 113 premature infants.

\section{Discussion}

The Quran says «Prohibited to you [for marriage] are your sisters through nursing. but if the marriage was not consumed, this is not a sin from you» Surah 4 An-Nisa', verse 23 .

Opinions of the Fatwa differ, but human milk donation is ultimately considered to be an act of charity. It is a very noble deed to save the lives of premature infants [1]. According to Yusuf Al-Qaradawi: "there is no doubt that milk banks were created to help premature infants. This act is noble, fully supported by the Muslim community. Islam calls for assistance to help all persons in need, particularly premature infants." The Imam IbnHazm (994-1064), a Muslim theologian, wrote that if a baby drinks the milk from a bottle, pumped from the breast, or it is poured into his mouth, the sibling bond is not created and marriage is not forbidden. Al-Layth Ibn Saad (713-791) and Imam Dawud agreed with this opinion, "human milk donation is tolerated as long as the milk is coming to the baby by other means than sucking".

We interviewed Cheikh Bouzidi, who works at the Paris Mosque. He confirmed that human milk donation is an act of charity. It is tolerated, as long as the milk is not given directly by the breast (a reference can be found on the ADLF website http://www.perinat-france.org/, http://.lactarium-idf.aphp.fr.). This act of charity is the third pillar of Islam, which is imposed on the rich to help the poor.

During the processing of DHM, the milk of several mothers is pooled, thoroughly mixed, and gently heated using the Holder Method of pasteurization $\left(62.5^{\circ} \mathrm{C} 30\right.$ minutes). The milk is then fortified by adding vitamins, irons, proteins, etc., refrozen, and packaged. Before donation, screening blood tests for viral and xenobiotic infections are performed. Human milk donation is anonymous and milk banks are not authorized to keep the donor's identity, nor to consider the sex of the receiving child. Alnakshabandi et al. [2] proposed a new approach to milk banking, called the Conditional Identified Milk Banking System (CIMBS). In this system, both the donor's and recipient's identities are accessible to all parties through a voluntary registry, and milk-pooling is limited to three milk donors.

The transmission of biological, genetic, and epigenetic factors through breast milk is a potential concern. Genetic and biological factors found in human milk thus have to be taken into account, such as micro RNAs (miRNAs), which are short, noncoding RNAs involved in the regulation of gene expression and can be found in the bloodstream [3]. Microscopic cell particles (i.e. exosomes, micro- and nanoparticles) are also found in human milk. Stem cells are also present in breast milk and are another important factor that supports the milk-kinship hypothesis. The presence of small numbers of maternal cells or DNA in offspring is known as maternal-fetal microchimerism. This transfer of cells from one individual to another occurs via breast milk and cells of maternal origin can persist in offspring for years. Some miRNAs are specifically expressed in stem cells to regulate the expression of key genes. Thus, if epigenetic modifications coming from mother's milk can be hereditary, the new epigenetic marks could be expressed, in certain cases, in the offspring [3]. Thus, a Turkish group has reasoned that miRNA found in human milk is an argument for not opening human milk banks. However, two studies have argued that miRNAs transmitted through human milk are destroyed in the gastrointestinal tract $[4,5]$. Other studies have shown that miRNA subjected to harsh conditions are stable and resistant to several freeze-thaw cycles and incubation for one hour in an acidic (PH 1) solution [6]. However, Qi Zhou et al. have shown that exogenous miRNA is more rapidly degraded at high temperature $\left(100^{\circ} \mathrm{C}\right.$ for 10 min) than endogenous miRNA. Holder pasteurization during donor human milk processing could do the same damage [7]. These two arguments support that miRNA found in human milk cannot be directly responsible for epigenetic or genetic changes in offspring.

Turkish religious officers have stated that they would only approve the establishment of an alternative human milk bank in which milk would be pooled from a maximum of three donors and up to three recipients, whose identities are known by one another, would be allowed to use donor milk from each milk pool [8, 9]. The various religious, cultural, biological, and epigenetic aspects exposed by this study and the uniqueness of the characteristics of human milk support human milk donation by Muslim mothers and Muslim children to receive DHM [10].

\section{Conclusion}

Milk banks should be created in Muslim countries to help premature infants. There will be no " milk kinship » between individuals receiving milk from the same donor and the donor and baby will not be siblings. The low rate of breastfeeding at six months in Muslim countries $(24 \%$ in Saudi Arabia, $10 \%$ in Kuwait: $14 \%$ in Indonesia, and $1.3 \%$ in Turkey) indicates a true need to develop milk banks in these countries. Human milk banks are vital for providing donor milk to preterm infants for whom there are maternal or postnatal barriers to receiving their own mother's milk. The main goal is the optimal nutrition of every premature baby [11]. 


\section{References}

[1] Ghaly M. Milk banks through the lens of Muslim scholars: one text in two contexts. Bioethics. 2012: 26: 1 17-27.

[2] Alnakshabandi K, Fiester A. Creating religiously compliant milk banks in the Muslim world: a commentary. Paediatrics and International Child Health. 2016; 36: 4-6.

[3] Ozkan H, Tuzun F, Kumral A, DumanN, Milk kinship hypothesis in light of epigenetic knowledge. ClinicalEpigenetics. 2012; 18: 4-14.

[4] Witwer KW, Hirschi KD. Transfer and functional consequences of dietary microRNAs in vertebrates: concepts in search of corroboration: negative results challenge the hypothesis that dietary xenomiRs cross the gut and regulate genes in investing vertebrates, but important questions persist. Bioessays. 2014; 36: 394-406.

[5] Dickinson B, Zhang Y, Petrick JS, Heck G, Ivashuta S, Marshall WS. Lack of detectable oral bioavailability of plant microRNAs after feeding in mice. Nature Biotechnology. 2013; 31: 965-7.

[6] Kosaka N, Izumi H, Sekine K, Ochiya T. microRNA as a new immune-regulatory agent in breast milk. Silence. 2010; 1: 1 7.

[7] Zhou Qi, Li M, Wang X, Li Q, Wang T, Zhu Q, Zhou X, Wang $\mathrm{X}$, Gao X, Li X. Immune-related micro RNAs are abundant in breast milk exosomes. International Journal of Biological Sciences. 2012; 8: 1 18-23.

[8] Karadag A, Ozdemir R, Ak M, Ozer A, Dogan DG, Elkiran O. Human milk banking and milk kinship: Perspectives of mothers in a Muslim country. J Trop Pediatr. 2015; 61:188-96.

[9] Ozdemir R, Ak M, Karatas M, Ozer A, Dogan DG, Karadag A. Human milk banking and milk kinship: perspectives of religious officers in a Muslim country. J Perinatol. 2015; 35:137-41.

[10] Williams TC, Butt MZ, Mohinuddin SM, Ogilvy-Stuart AL, Clarke M, Weaver GA, Shafi MS. Donor human milk for Muslim infants in the UK. Journal of Biology and science. 2012; 8; 1 18-23.

[11] Khalil A, Buffin R, Sanlaville D, Picaud JC. Milk kinship is not an obstacle to using donor human milk to feed preterm infants in Muslim countries. Acta Paediatr. 2016; 105:462-7. 